\title{
Availability and Nutritional Values of Selected Non Vertebrate Wildlife Species in Niger Delta, Nigeria
}

\author{
Henry M. Ijeomah ${ }^{1}$, Ayebanengiyefa L. Alagoa ${ }^{1} \&$ Ann U. Ijeomah ${ }^{2}$ \\ ${ }^{1}$ Department of Forestry and Wildlife Management, University of Port Harcourt, Port Harcourt, Nigeria \\ ${ }^{2}$ Department of Biochemistry and Molecular Biology, Nasarawa State University, Keffi, Nigeria \\ Correspondence: Henry M. Ijeomah, Department of Forestry and Wildlife Management, University of Port \\ Harcourt, Port Harcourt, Nigeria. Tel: 234-806-034-4776. E-mail: henryijeomah@yahoo.com
}

Received: November 2, 2012 Accepted: January 13, 2013 Online Published: January 22, 2013

doi:10.5539/enrr.v3n2p10

URL: http://dx.doi.org/10.5539/enrr.v3n2p10

\begin{abstract}
The study investigated the sources, availability, and nutritional values of Crab (Callinectes spp); Oyster (Ostrea edulis); Periwinkle (Littorina irrorata); and the Raphia palm weevil larvae (Rhynchophorus phoenicis) in the study area. Bassambiri and Ogbolomabiri in Bayelsa State and Isaka and Okrika Communities of Rivers State were selected at random from other communities in Niger Delta with abundance of these selected species. Data for the study were obtained through administration of structured questionnaire, in-depth-interview and personal observation. A set of questionnaires was administered systematically to $4 \%$ of household representatives in the four selected communities. In all, a total of 301 households were sampled in the four communities. Data obtained were analysed using descriptive statistics. The species are harvested manually or with local traps. According to many respondents $(54.46 \%)$ Crabs are more abundant in the rainy season while the Oyster, Periwinkle and Edible maggot are more abundant during the dry season. Although Periwinkle, Oyster, Crab and Raphia palm weevil larvae contain Sodium, Phosphorus, Potassium, Magnesium, Calcium and Iron, Crab is relatively the best source of Calcium among the species, while Oyster is the least since the shells are entirely removed during extraction. Harvesting of these species is done by most members of households. Boiling is the most preferred method for processing these species because it makes them tasty $(64.03 \%)$. However, majority $(83.33 \%)$ of respondents from Ogbolomabiri community in Bayelsa State prefer smoking the species because it increases their shelf life. These non-vertebrate wildlife species are of utmost importance to the rural people of the Niger Delta thus their decline and depletion subsequently could result in loss of income, malnourishment and overall poverty.
\end{abstract}

Keywords: non vertebrates wildlife species, nutritional values, Niger Delta, biodiversity utilisation

\section{Introduction}

The term wildlife encompasses every form of life that exists in a forest. A forest is the totality of wild lands or non-domesticated lands (Okali, personal communication). This definition does give coverage to all land forms in their natural state including mountains, streams, rivers, deserts, oceans and sand dunes. Forests provide an array of products (including bush meat) which are used by man for survival. Though emphasis was formerly laid only on timber, other products from wild lands were neglected (Olajide, 2003; Panayou \& Ashton, 1992). This made timber the most popular among other forest products.

With recent developments, the essential roles played by other forest products (particularly the wild animal component) at various levels and forms in different localities have become recognized. Consequently, forest resources are being classified into timber and non-timber forest products (Okafor et al., 1994). Non-timber forest products therefore are forest materials derived from faunal and floral resources other than timber. They include herbs, leaves, latex, gum, charcoal, clay and animals (Udofia, Offiong, Ijeomah, \& Etefia, 2009).

There is hardly any community that does not consume one or more species of animal as bushmeat (Ayodele, Alarape, \& Ebin, 1999). Bushmeat is a major source of income and dietary animal protein and minerals in the rural areas as it is relatively cheap, readily available and therefore frequently utilized. Consumption of several species of wild animals or bushmeat on sustainable basis is one of the sure ways of balancing the national animal protein deficit in a country like Nigeria. Though vertebrates such as Buffalo (Syncerus caffer), antelopes, rodents 
and other big games are always given more regard by researchers, the invertebrate species-animals without backbones, such as crickets, crabs, locusts, snails, oysters, termites, which are amongst the more available and more frequently utilized in different forms are rarely studied.

Meat from these invertebrates on regular basis is more important in rural nutrition than those of domestic species and big games because, most of these species have relatively lesser market value (on individual basis) especially in the local markets. As a result of this, both domestic animals and larger games are rarely eaten by subsistence farmers, hunters and their families. Instead, small non-vertebrate wildlife species with little market values often neglected by researchers serve as nutrients and prevent many nutrient deficient diseases. Farming of insects for consumption and export is a source of substantial income to rural Papau New Guineans (Ogogo, 2008). The Niger Delta region was a major concern to Nigeria and the international community due to the high level of restiveness therein as majority of the inhabitants struggle for survival. For peace, development, and food security in the Niger Delta region, sources of households' (especially the rural poor) basic nutrition should be studied and monitored for sustainable provision of products.

Consumption of wild animals for food has been of immense importance in maintaining the health status of rural inhabitants over the years through their nutrient contents. However, these nutrient contents and their respective proportions in each species at various localities are yet to be known. More so information on the abundance, seasonality, method of harvesting and processing of these available species are yet to be documented. There is need to study these methods for further improvement on the techniques of harvesting and processing to ensure efficiency and effectiveness in their supply.

Among the studies on wildlife species in the Niger Delta none has focused on harvesting and processing of Crab, Periwinkle, Oyster, Edible maggot and insects. In order to prevent future shortage in animal protein supply, the maximum utilization of non-vertebrate wildlife species, which are sources of mineral in the area, has to be assured. The objectives of the study are therefore to:

- Determine the sources and availability of these species in the study areas.

- Investigate the effects of seasonality on availability of the species, and challenges involved in harnessing these species.

- Assess the contribution of the species to the rural economies of the study areas.

- Determine the processing methods and nutritional values of the species.

\section{Materials and Method}

\subsection{Study Area}

The Niger Delta region of Nigeria was selected for this study based on the fact that it is one of the highest sources of petroleum on earth. Though petroleum is the mainstay of the Nigerian economy; the region from where it is derived has suffered neglects and environmental pollution for decades. This has resulted in economic hardship of the inhabitants, and frequent restiveness in the region.

The Niger Delta comprises nine states which are Abia, Akwa-Ibom, Bayelsa, Cross-Rivers, Delta, Edo, Imo, Ondo and Rivers (Figure 1). These nine states, which all produce crude oil, are found in the swamp/fresh water forest ecological zone. 


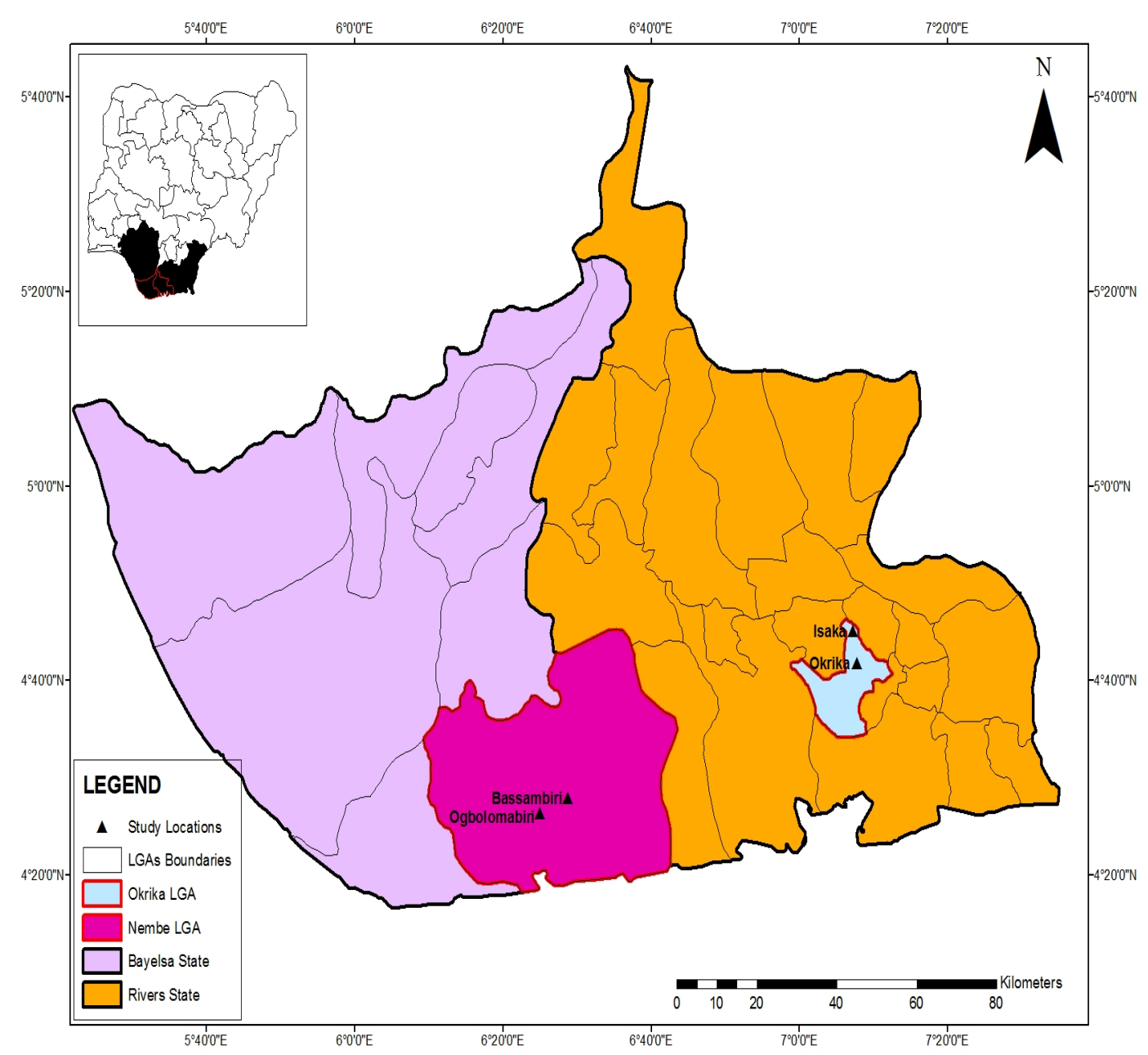

Figure 1. Map of Bayelsa/ Rivers states showing the study areas

Source: Field Survey, 2011.

Bayelsa and Rivers states were selected based on relative abundance and utilization of Crab (Callinectes species), Edible maggot: Raphia Palm weevil larva-(Rhynchophorus phoenicis), Oyster (Ostrea edulis) and the marsh Periwinkle (Littorina irrorata) by the households therein.

From a list of local government areas that have these selected species in abundance in Rivers and Bayelsa States one from each state was randomly selected. Finally two communities were randomly selected from each local government area. In all, four communities were selected. Isaka and Okrika: Bassambiri and Ogbolomabiri communities were selected from Okrika and Nembe Local Government Areas in Rivers and Bayelsa States respectively as study area.

\subsection{Method of Data Collection}

a. Data for the research project were collected using structured questionnaire, in-depth interview, field observation and laboratory analysis. A set of questionnaires was randomly administered to $4 \%$ of the total number of households in the selected communities. The number of households were determined by 'Listing of households' as is consistent with Omonona (2000) and Ijeomah (2007).

Then the set of questionnaires were administered systematically to males and females in such a way as to have equal number of male and female respondents as shown in Table 1a. 
Table 1. Proportional allocation of respondents in selected communities

\begin{tabular}{lccccc}
\hline Communities & No. of households & $4 \%$ of households & No. of males & No. of females & No. sampled \\
\hline Ogbolomabiri & 2049 & 81 & 40 & 41 & 81 \\
Bassambiri & 1803 & 72 & 36 & 36 & 72 \\
Okrika & 1993 & 79 & 39 & 39 & 78 \\
Isaka & 1743 & 69 & 35 & 35 & 70 \\
Total number of household sampled in the four selected communities & \multicolumn{3}{c}{301} \\
\hline
\end{tabular}

Source: Field Survey, 2011.

In all a set of 301 questionnaires to households were administered (Table 1).

b. In-depth interviews were conducted with indigenes of the four communities who have lived therein for a minimum period of ten years and are therefore quite knowledgeable about harvesting, processing and utilization of the non-vertebrate wildlife resources in the community.

c. Field observation: The study areas (sites) where these selected non-vertebrate species are available were visited with canoes to collect samples of the species for laboratory analysis, methods of collection and processing of these species were also observed.

d. Laboratory analysis: Mineral content ( $\mathrm{Ca}, \mathrm{Na}, \mathrm{K}, \mathrm{P}, \mathrm{Mg}$ and $\mathrm{Fe}$ ) analyses were carried out on the species using standard laboratory methods (AOAC, 2000) such as titration, Atomic absorption spectrometer (AAS) and ultraviolent spectrophotometer.

\subsubsection{Laboratory Analysis}

Porcelain plates were weighed on a weighing balance, then small quantities of the samples were measured into them, after wards re-weighing was done and the contents were put into a furnace, to turn the samples to ash. Upon cooling $1 \mathrm{ml}$ Hydrochloric acid $(\mathrm{HCl})$ was added to it for digestion, and then filtered into a beaker, and water was added to attain a $50 \mathrm{ml}$ mark, the content was emptied into a bottle with lid. From the substrate (50 $\mathrm{ml}), 1 \mathrm{ml}$ was collected into a conical flask, $4 \mathrm{ml}$ Ammonium molybdate, and $5 \mathrm{ml}$ sodium hydroxide $(\mathrm{NaOH})$ was also added, then 2 drops of naphthalene indicator was added and titrated. The end point (titre value) was used to estimate the values for calcium (Ca) (see calculation). For magnesium ( $\mathrm{Mg}$ ), sodium ( $\mathrm{Na}$ ), potassium (k), and iron $(\mathrm{Fe})$ atomic absorption spectrometer was used to determine these minerals, readings were in milligram per litre, the values were then converted to milligram per $100 \mathrm{gram}(\mathrm{mg} / 100 \mathrm{~g})$ as illustrated below:

Calculation

$$
\begin{gathered}
\text { Density = mass } / \text { volume } \\
\text { Density }=\text { mass }(\mathrm{g}) / \text { volume }(\mathrm{ml})
\end{gathered}
$$

(Equation 1)

Conversion factor 1000 (since $\mathrm{ml} * 1000=1$ litre)

To convert $\mathrm{mg}$ to gram $=$ Concentration of solution $(\mathrm{mg} / \mathrm{l}) /$ density $(\mathrm{g} / \mathrm{l})$

Since litres cancel out, $\mathrm{mg} / \mathrm{g} * 100=\mathrm{mg} / 100 \mathrm{~g}$.

Where:

Mass $(g)=($ dry weight of container with dry mass of the species - weight of the container $)$

Volume $(\mathrm{ml})=50 \mathrm{ml}$

Concentration $(\mathrm{mg} / \mathrm{l})=$ titre values and values from the AAS and UV Spectrophotometer readings.

\subsection{Data Analysis}

Data collected were analysed using descriptive statistics in form of frequency of counts, percentages, and presented in tables, bar charts and pie charts.

\section{Results}

\subsection{Sources and Availability of the Non Vertebrate Wildife Species}

Table 2 shows that many respondents obtain Crab by buying (45.54\%), while the Oyster (43.23\%) and Periwinkle were mostly harvested. About $58.42 \%$ of respondents considered the harvesting of Oyster comparatively difficult 
unlike that of Crab and Periwinkle (Table 3). Figure 2 shows that most respondents have observed decreases in the harvests of these non vertebrate wildlife species especially Periwinkle (54.79\%) and Oyster $(51.16 \%)$. Some respondents linked the declines in Oyster and Crab to mainly water pollution (36.96\%) and overexploitation $(20.46 \%)$ respectively (Table 4$)$.

Table 2. Different ways of procuring the non-vertebrate species in the study area

\begin{tabular}{lllllllllll}
\hline \multicolumn{1}{c}{ Frequencies } & & & & \multicolumn{3}{c}{ Percentages \% } \\
\multicolumn{1}{l}{} & I & II & III & IV & TOTAL & TOTAL\% & I\% & II\% & III\% & IV\% \\
\hline Ways of procurement & & & & & & & & & & \\
Crab & & & & & & & & & & \\
Gifts & 5 & 3 & 0 & 0 & 8 & 2.64 & 62.5 & 37.5 & 0 & 0 \\
Harvesting & 35 & 30 & 25 & 12 & 102 & 33.66 & 34.31 & 29.41 & 24.51 & 11.76 \\
Purchasing & 25 & 29 & 32 & 52 & 138 & 45.54 & 18.12 & 21.01 & 23.19 & 37.68 \\
no response & 16 & 10 & 22 & 5 & 53 & 17.49 & 30.19 & 18.87 & 41.51 & 9.43 \\
Oyster & & & & & & & & & & \\
Gifts & 0 & 0 & 0 & 1 & 1 & 0.33 & 0 & 0 & 0 & 100 \\
Harvesting & 50 & 28 & 27 & 26 & 131 & 43.23 & 38.17 & 21.37 & 20.61 & 19.85 \\
Purchasing & 9 & 31 & 30 & 42 & 112 & 36.96 & 8.04 & 27.68 & 26.79 & 37.5 \\
no response & 22 & 13 & 22 & 0 & 57 & 18.81 & 38.6 & 22.81 & 38.6 & 0 \\
Periwinkle & & & & & & & & & & \\
as gifts & 7 & 8 & 0 & 0 & 15 & 4.95 & 46.67 & 53.33 & 0 & 0 \\
by harvesting & 72 & 47 & 32 & 43 & 194 & 64.03 & 37.11 & 24.23 & 16.49 & 22.16 \\
Purchasing & 2 & 8 & 28 & 25 & 63 & 20.79 & 3.17 & 12.7 & 44.44 & 39.68 \\
no response & 0 & 9 & 19 & 1 & 29 & 9.57 & 0 & 31.03 & 65.52 & 3.45 \\
Raphia palm & weevil larva & & & & & & & & \\
As gifts & 0 & 0 & 0 & 0 & 0 & 0 & & & & \\
Harvesting & 12 & 1 & 1 & 1 & 15 & 4.95 & 80 & 6.67 & 6.67 & 6.67 \\
Purchasing & 53 & 27 & 27 & 9 & 116 & 38.28 & 45.69 & 23.28 & 23.28 & 7.76 \\
no response & 16 & 44 & 51 & 59 & 170 & 56.11 & 9.41 & 25.88 & 30 & 34.71 \\
\hline
\end{tabular}

Source: Field Survey, 2011.

I represent - Ogbolomabiri community, Bayelsa state.

II represent - Bassambiri community, Bayelsa state.

III represent - Okrika community, Rivers state.

IV represent - Isaka community, Rivers state.

TOTAL represent - The total of 301 (respondents out of the total percentage of households sampled).

Table 3. Perceived assessment of the mode of harvesting the species

\begin{tabular}{lllllllllll}
\hline \multicolumn{1}{c}{} & \multicolumn{3}{c}{ Frequencies } & & & \multicolumn{5}{c}{ Percentages\% } \\
\multicolumn{1}{l}{} & I & II & III & IV & TOTAL & TOTAL\% & I\% & II\% & III\% & IV\% \\
\hline $\begin{array}{l}\text { Mode of harvesting } \\
\text { Crab }\end{array}$ & & & & & & & & & & \\
Difficult & 28 & 22 & 21 & 24 & 95 & 31.35 & 29.47 & 23.16 & 22.11 & 25.26 \\
not difficult & 53 & 40 & 39 & 45 & 177 & 58.42 & 29.94 & 22.6 & 22.03 & 25.42 \\
no response & 0 & 10 & 20 & 0 & 30 & 9.9 & 0 & 33.33 & 66.67 & 0 \\
Oyster & & & & & & & & & & \\
Difficult & 56 & 37 & 28 & 56 & 177 & 58.42 & 31.64 & 20.9 & 15.82 & 31.64 \\
not difficult & 25 & 25 & 26 & 13 & 89 & 29.37 & 28.09 & 28.09 & 29.21 & 14.61 \\
\hline
\end{tabular}




\begin{tabular}{lllllllllll}
\hline no response & 0 & 10 & 25 & 0 & 35 & 11.55 & 0 & 28.57 & 71.43 & 0 \\
Periwinkle & & & & & & & & & & \\
Difficult & 3 & 8 & 22 & 55 & 88 & 29.04 & 3.41 & 9.09 & 25 & 62.5 \\
not difficult & 78 & 53 & 38 & 13 & 182 & 60.07 & 42.86 & 29.12 & 20.88 & 7.14 \\
no response & 0 & 11 & 19 & 1 & 31 & 10.23 & 0 & 35.48 & 61.29 & 3.23 \\
Raphia palm & weevil larva & & & & & & & & \\
Difficult & 51 & 12 & 13 & 0 & 76 & 25.08 & 67.11 & 15.79 & 17.11 & 0 \\
not difficult & 30 & 40 & 2 & 0 & 72 & 23.76 & 41.67 & 55.56 & 2.78 & 0 \\
no response & 0 & 20 & 64 & 69 & 153 & 50.5 & 0 & 13.07 & 41.83 & 45.1 \\
\hline
\end{tabular}

Source: Field Survey, 2011.

I represent - Ogbolomabiri community, Bayelsa State.

II represent - Bassambiri community, Bayelsa State.

III represent - Okrika community, Rivers State.

IV represent - Isaka community, Rivers State.

TOTAL represent - The total of 301 (respondents out of the total percentage of households sampled).

Table 4. Distribution of respondents based on perceived causes of species' decline in the study area

\begin{tabular}{|c|c|c|c|c|c|c|c|c|c|c|}
\hline & \multicolumn{4}{|c|}{ Frequencies } & \multirow[b]{2}{*}{ TOTAL } & \multirow[b]{2}{*}{ TOTAL $\%$} & \multicolumn{4}{|c|}{ Percentages $\%$} \\
\hline & I & II & III & IV & & & $\mathrm{I} \%$ & $\mathrm{II} \%$ & III\% & $\mathrm{IV} \%$ \\
\hline \multicolumn{11}{|l|}{ Cause of decline } \\
\hline \multicolumn{11}{|l|}{$\mathrm{Crab}$} \\
\hline Education & 22 & 0 & 5 & 14 & 41 & 13.53 & 53.66 & 0 & 12.2 & 34.15 \\
\hline Overexploitation & 0 & 32 & 16 & 14 & 62 & 20.46 & 0 & 51.61 & 25.81 & 22.58 \\
\hline water pollution & 0 & 6 & 32 & 7 & 45 & 14.85 & 0 & 13.33 & 71.11 & 15.56 \\
\hline under exploitation & 0 & 0 & 5 & 0 & 5 & 1.65 & 0 & 0 & 100 & 0 \\
\hline \multicolumn{11}{|l|}{ Oyster } \\
\hline Education & 7 & 0 & 5 & 24 & 36 & 11.88 & 19.44 & 0 & 13.89 & 66.67 \\
\hline Overexploitation & 11 & 15 & 10 & 29 & 65 & 21.45 & 16.92 & 23.08 & 15.38 & 44.62 \\
\hline water pollution & 52 & 17 & 31 & 12 & 112 & 36.96 & 46.43 & 15.18 & 27.68 & 10.71 \\
\hline less river saltiness & 5 & 3 & 0 & 0 & 8 & 2.64 & 62.5 & 37.5 & 0 & 0 \\
\hline \multicolumn{11}{|l|}{ Periwinkle } \\
\hline Education & 9 & 0 & 5 & 4 & 18 & 5.94 & 50 & 0 & 27.78 & 22.22 \\
\hline Overexploitation & 0 & 9 & 9 & 29 & 47 & 15.51 & 0 & 19.15 & 19.15 & 61.7 \\
\hline water pollution & 2 & 11 & 32 & 7 & 52 & 17.16 & 3.85 & 21.15 & 61.54 & 13.46 \\
\hline \multicolumn{11}{|c|}{ Raphia palm weevil larvae } \\
\hline Education & 6 & 0 & 0 & 0 & 6 & 1.98 & 100 & 0 & 0 & 0 \\
\hline under exploitation & 11 & 9 & 0 & 0 & 20 & 6.6 & 55 & 45 & 0 & 0 \\
\hline
\end{tabular}

Source: Field Survey, 2011.

I represent - Ogbolomabiri community, Bayelsa State.

II represent - Bassambiri community, Bayelsa State.

III represent - Okrika community, Rivers State.

IV represent - Isaka community, Rivers State.

TOTAL represent - The total of 301 (respondents out of the total percentage of households sampled). 


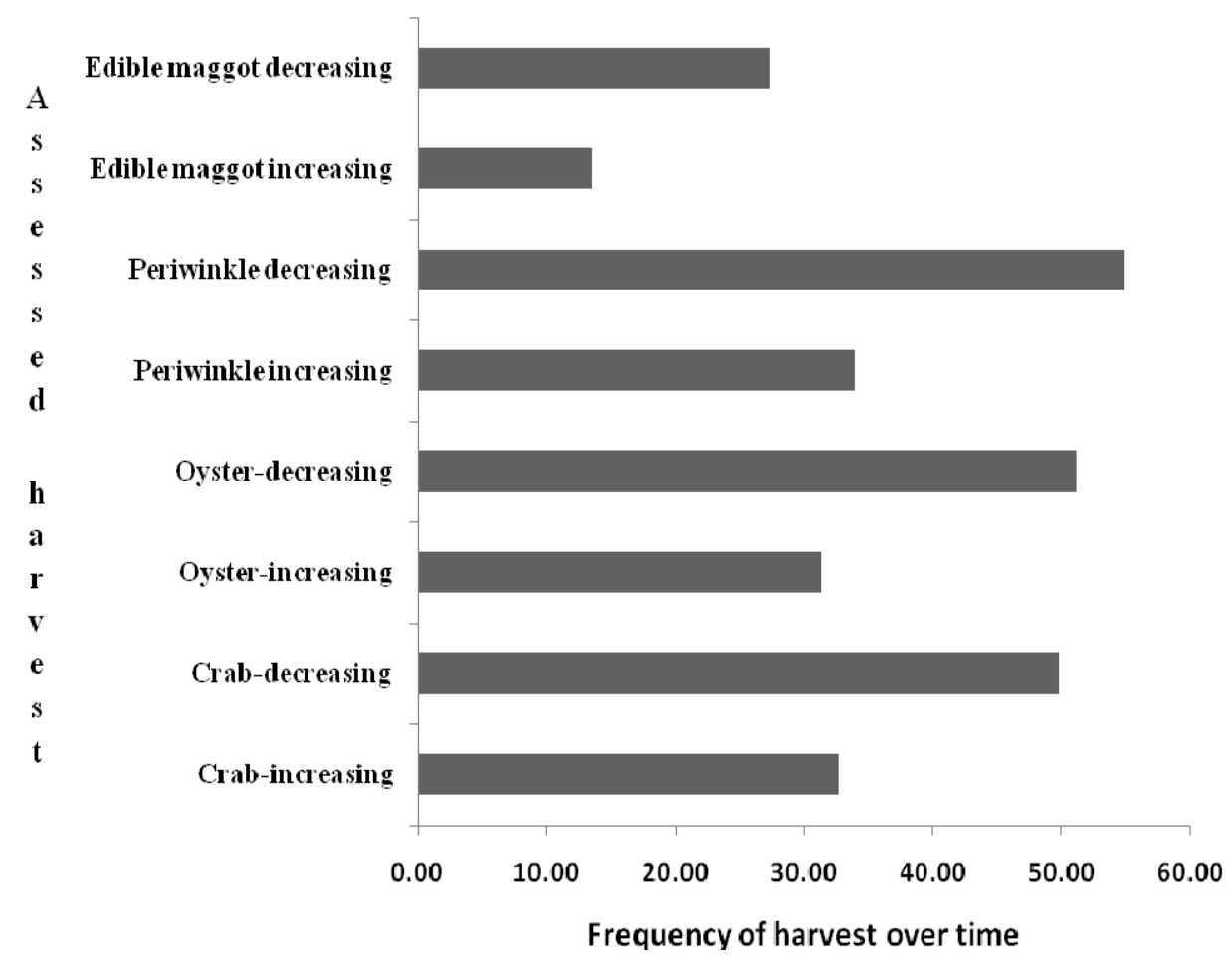

Figure 2. Distribution of respondents based on Perceived assessment of harvesting trend of the species over the years

Source: Field Survey, 2011.

Crab increasing $=$ Crab species harvested have increased over the years.

Crab decreasing $=$ Crab species harvested have decreased over the years.

Oyster increasing $=$ Oyster species harvested have increased over the years.

Oyster decreasing $=$ Oyster species harvested have decreased over the years.

Periwinkle increasing $=$ Periwinkle species harvested have increased over the years.

Periwinkle decreasing $=$ Periwinkle species harvested have decreased over the years

Edible maggot increasing $=$ Edible maggot species $($ Raphia palm weevil larva) harvested have increased over the years.

Edible maggot decreasing $=$ Edible maggot species (Raphia palm weevil larva) harvested have decreased over the years.

\subsection{Effect of Seasonality on Species' Availability}

Table 5 shows that seasonality does not affect the availability of Periwinkle (77.23\%) and Crab (47.52\%) even though most respondents (54.46\%) claimed that Crabs are more abundant in the rainy season compared to dry season (Figure 3). Most respondents were not well equipped with knowledge of the edible maggot. With exception of Edible maggot, most respondents were satisfied with quantity of the non vertebrate wildlife species harvested (Figure 4).

Table 5. Effects of season on species' availability as perceived by respondents

\begin{tabular}{lllllllllll}
\hline & \multicolumn{3}{c}{ Frequency } & & \multicolumn{8}{c}{ Percentage\% } \\
& I & II & III & IV & TOTAL & TOTAL\% & I\% & II\% & III\% & IV\% \\
\hline $\begin{array}{l}\text { Effect of Season } \\
\begin{array}{l}\text { Crab } \\
\text { Affected }\end{array}\end{array}$ & & & & & & & & & & \\
\hline
\end{tabular}




\begin{tabular}{lllllllllll}
\hline No effects & 48 & 16 & 52 & 28 & 144 & 47.52 & 33.33 & 11.11 & 36.11 & 19.44 \\
no/response & 0 & 22 & 13 & 0 & 35 & 11.55 & 0 & 62.86 & 37.14 & 0 \\
Oyster & & & & & & & & & & \\
Affected & 51 & 60 & 21 & 26 & 158 & 52.15 & 32.28 & 37.97 & 13.29 & 16.46 \\
No effects & 30 & 7 & 46 & 43 & 126 & 41.58 & 23.81 & 5.56 & 36.51 & 34.13 \\
no/response & 0 & 5 & 12 & 0 & 17 & 5.61 & 0 & 29.41 & 70.59 & 0 \\
$\begin{array}{l}\text { Periwinkle } \\
\text { Affected }\end{array}$ & 16 & 8 & 15 & 12 & 51 & 16.83 & 31.37 & 15.69 & 29.41 & 23.53 \\
No effects & 65 & 59 & 53 & 57 & 234 & 77.23 & 27.78 & 25.21 & 22.65 & 24.36 \\
no/response & 0 & 5 & 11 & 0 & 16 & 5.28 & 0 & 31.25 & 68.75 & 0 \\
Raphia palm weevil larvae & & & & & & & & \\
Affected & 30 & 42 & 5 & 1 & 78 & 25.74 & 38.46 & 53.85 & 6.41 & 1.28 \\
No effects & 31 & 7 & 18 & 0 & 56 & 18.48 & 55.36 & 12.5 & 32.14 & 0 \\
no/response & 20 & 23 & 56 & 68 & 167 & 55.12 & 11.98 & 13.77 & 33.53 & 40.72 \\
\hline
\end{tabular}

I represent - Ogbolomabiri community, Bayelsa State.

II represent - Bassambiri community, Bayelsa State.

III represent - Okrika community, Rivers State.

IV represent - Isaka community, Rivers State.

TOTAL represent - The total of 301 (respondents out of the total percentage of households sampled).

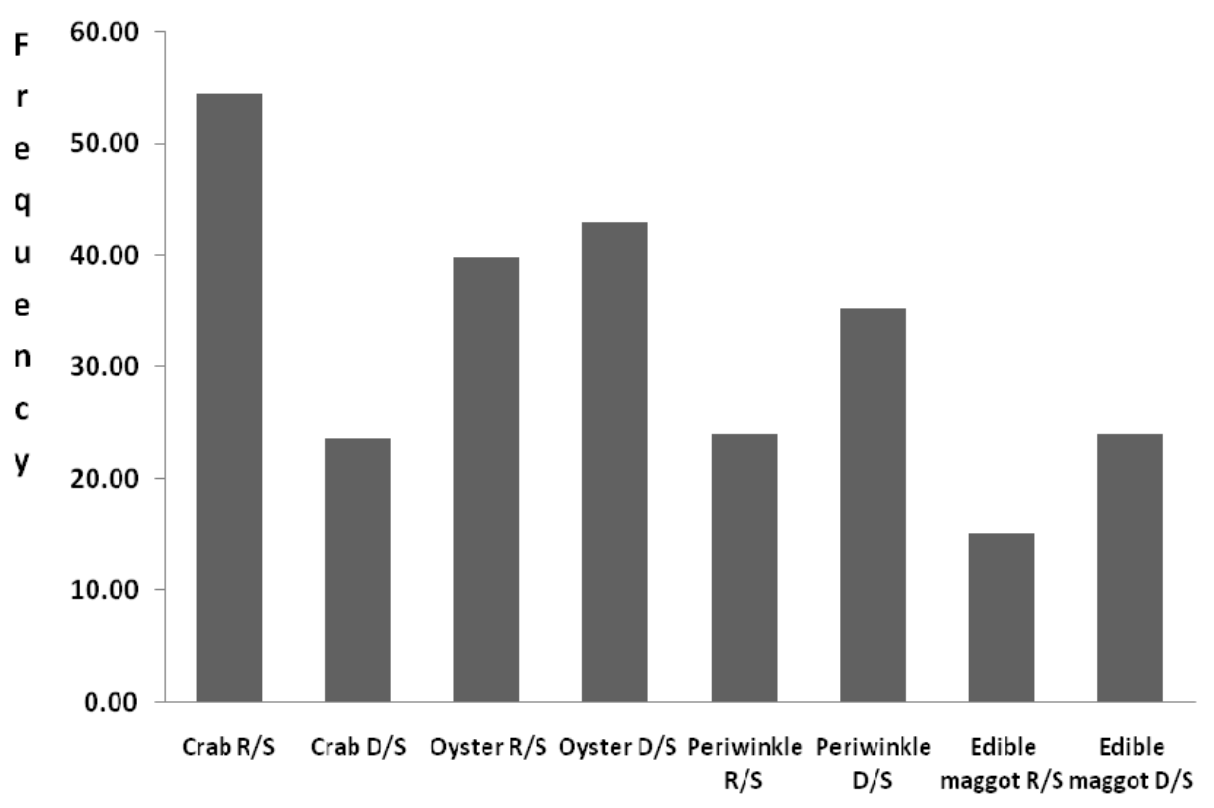

Seasons of species' abundance

Figure 3. Distribution of respondents based on perceived seasons of abundance of the species Source: Field Survey, 2011.

$\mathrm{Crab} \mathrm{R} / \mathrm{S}=\mathrm{Crab}$ species are more abundant in the rainy season.

$\mathrm{Crab} \mathrm{D} / \mathrm{S}=$ Crab species are more abundant in the dry season.

Oyster R/S = Oyster species are more abundant in the rainy season.

Oyster $\mathrm{D} / \mathrm{S}=$ Oyster species are more abundant in the dry season.

Periwinkle $\mathrm{R} / \mathrm{S}=$ Periwinkle species are more abundant in the rainy season.

Periwinkle $\mathrm{D} / \mathrm{S}=$ Periwinkle species are more abundant in the dry season. 
Edible maggot $\mathrm{R} / \mathrm{S}=$ Edible maggot species are more abundant in the rainy season.

Edible maggot $\mathrm{D} / \mathrm{S}=$ Edible maggot species are more abundant in the dry season.

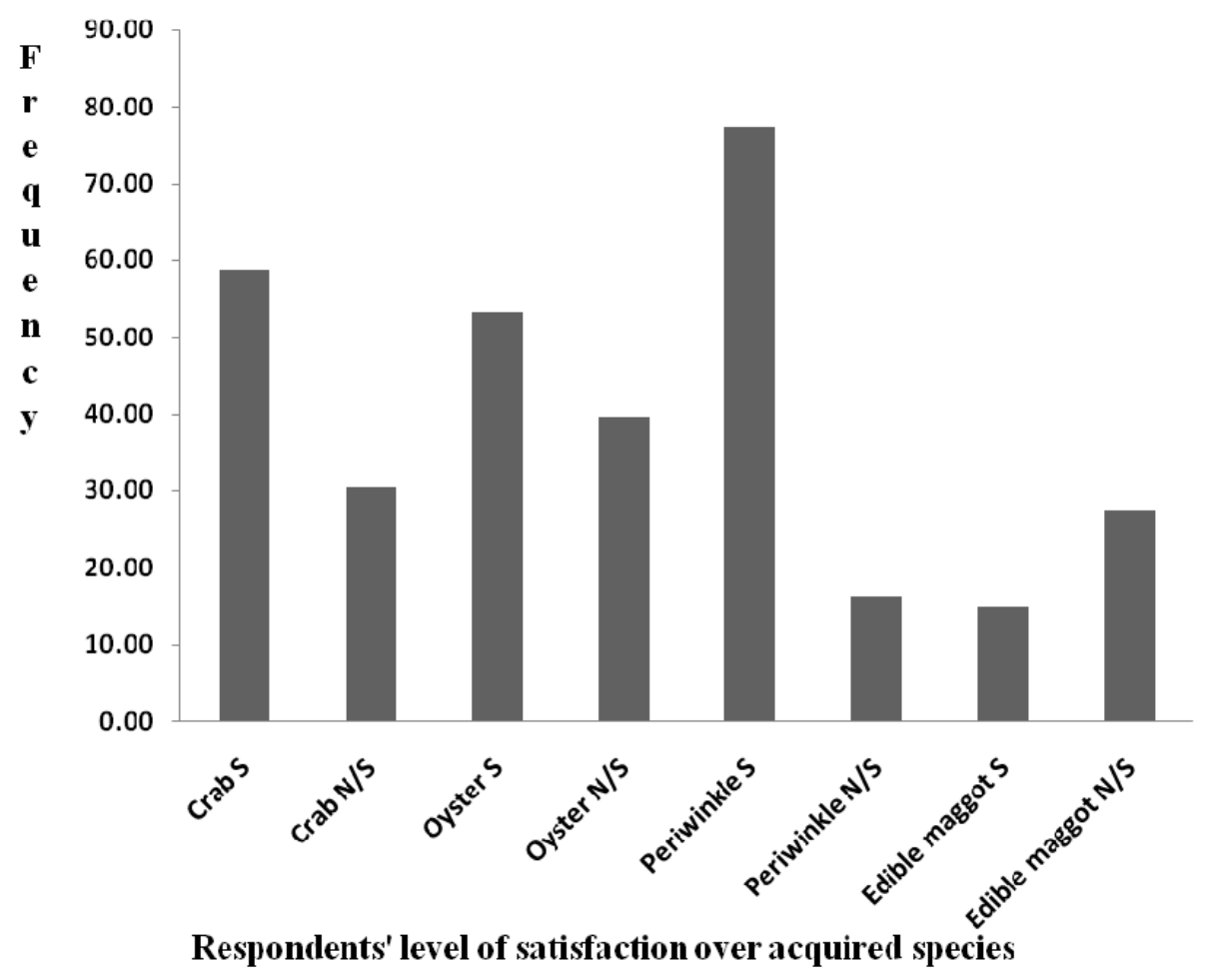

Figure 4. Assessment of respondents' satisfaction over quantity of species normally harvested for utilization Source: Field survey, 2011.

Crab $\mathrm{S}=$ Satisfied over the quantity of Crab acquired.

Crab N/S = Not satisfied over the quantity of Crab acquired.

Oyster $\mathrm{S}=$ Satisfied over the quantity of Oyster acquired.

Oyster N/S = Not satisfied over the quantity of Oyster acquired.

Periwinkle $\mathrm{S}=$ Satisfied over the quantity of Periwinkle acquired.

Periwinkle N/S = Not satisfied over the quantity of Periwinkle acquired.

Edible maggot $\mathrm{S}=$ Satisfied over the quantity of Raphia palm weevil larva (Edible maggot acquired).

Edible maggot N/S = Not satisfied over the quantity of Raphia palm weevil larva (Edible maggot acquired).

\subsection{Contribution of the Species to the Rural Economies}

Results on respondents' awareness of the methods of selling the species to generate income are presented in Figures 5, 6, 7 and 8. Figures 5, 6, and 7 show that Crab, Oyster, Periwinkle and Edible maggot are mostly sold attached or tied on sticks (46.86\%), cups $(54.21 \%)$, bags $(27.72 \%)$ and on sticks $(41.58 \%)$ respectively. Figure 8 reveals that Edible maggot is least sold in baskets $(0.66 \%)$. 


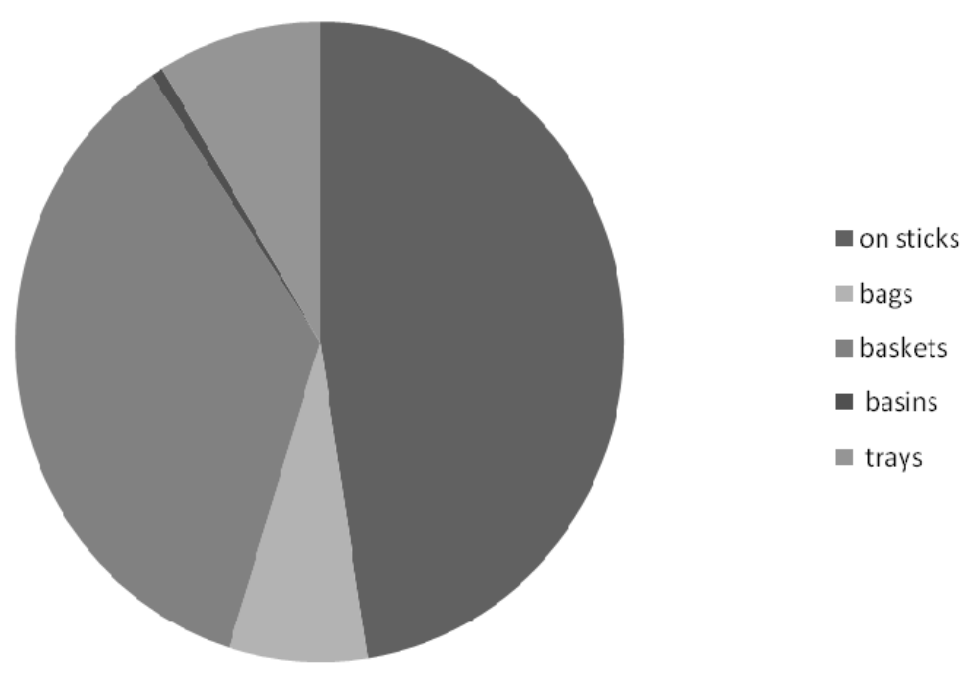

Figure 5. Distribution of respondents based on their awareness of various methods of selling Crab species Source: Field Survey, 2011.

Sticks $=$ sale of Crab tied on sticks.

Bags $=$ sale of Crab in bags.

Baskets $=$ sale of Crab in baskets.

Trays $=$ sale of Crab in trays.

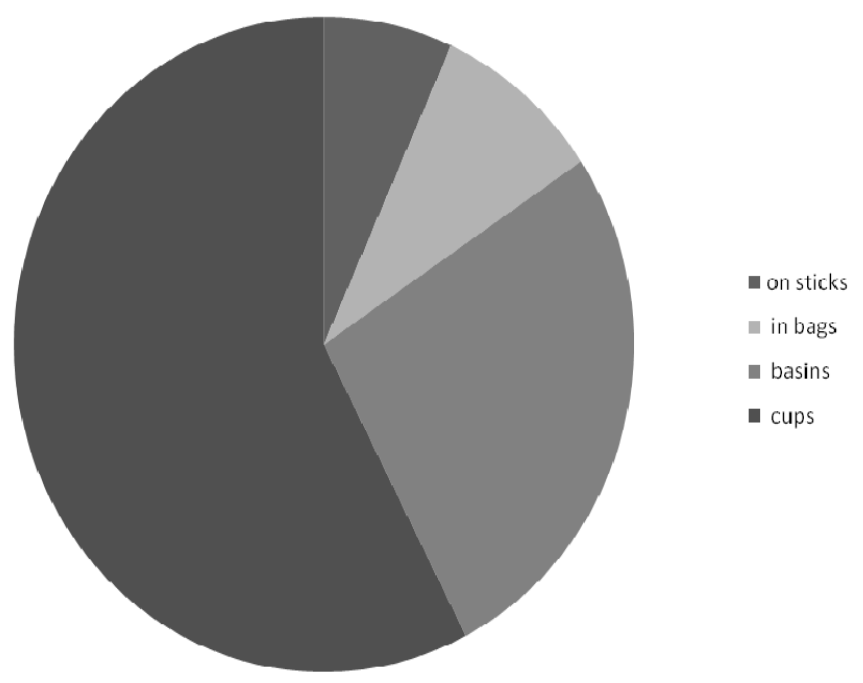

Figure 6. Distribution of respondents based on the modes of sales of Oyster

Source: Field Survey, 2011.

On sticks = sale of Oyster on mangrove roots/stems.

Bags $=$ sale of Oyster in bags.

Basins $=$ sale of Oyster in basins

Cups $=$ sale of Oyster in cups. 


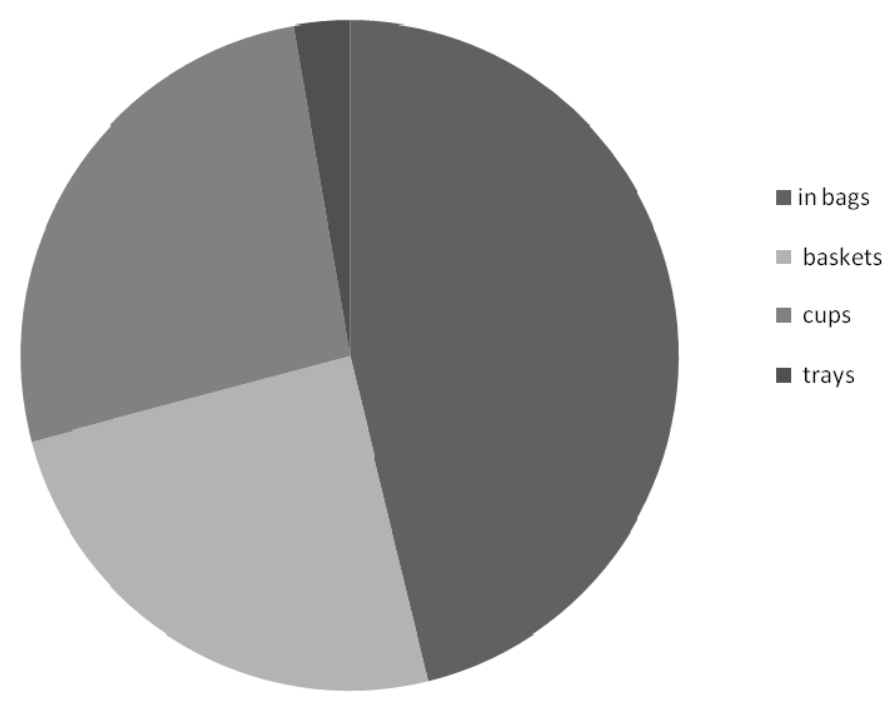

Figure 7. Distribution of respondents based on the modes of sales of Periwinkle species

Source: Field Survey, 2011.

Bags $=$ sale of Periwinkle in bags.

Baskets $=$ sale of Periwinkle in baskets.

Cups $=$ sale of Periwinkle in cups.

Trays $=$ sale of Periwinkle in trays.

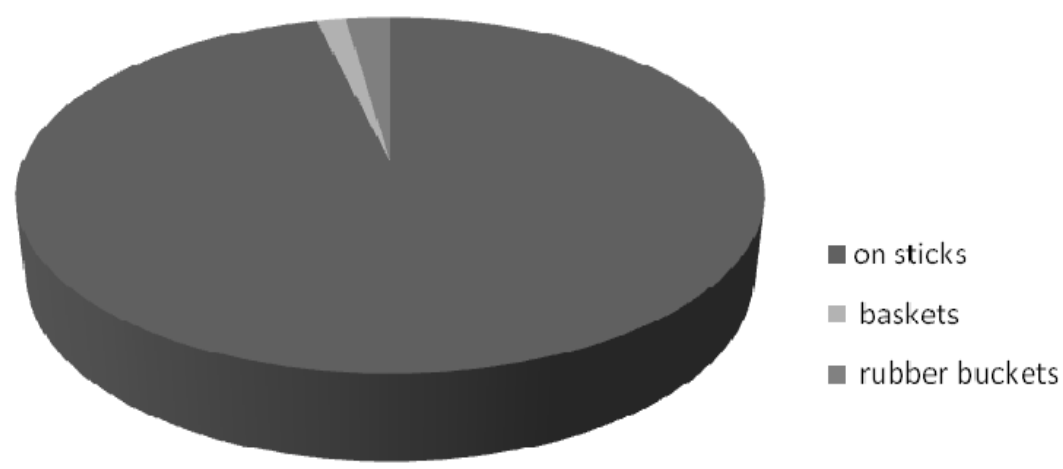

Figure 8. Distribution of respondents based on the modes of sale of Edible maggot species

Source: Field Survey, 2011.

Sticks $=$ sale of Edible maggot on sticks.

Baskets $=$ sale of Edible maggot in baskets.

Rubber buckets $=$ sale of Edible maggot in rubber buckets.

\subsection{Methods of Processing the Species}

Table 6 shows that respondents in the four sampled communities process the species mostly by boiling. Boiling is the most preferred method for processing these species (Table 7) because of the taste $(64.03 \%)$ (Table 8). However, majority (83.33\%) of respondents from Ogbolomabiri community in Bayelsa State prefer smoking the species because the shelf life is increased, if processed this way (Table 8). 
Table 6. Various ways of processing selected species in the study area

\begin{tabular}{lllllllllll}
\hline \multicolumn{1}{c}{ Frequency } & & & \multicolumn{7}{c}{ Percentage\% } \\
\multicolumn{1}{c}{ I } & II & III & IV & TOTAL & TOTAL\% & I\% & II\% & III\% & IV\% \\
\hline Way of processing & & & & & & & & & \\
Crab & & & & & & & & & & \\
Fried & 1 & 0 & 8 & 0 & 9 & 2.97 & 11.11 & 0.00 & 88.89 & 0.00 \\
Boiled & 39 & 42 & 58 & 33 & 172 & 56.77 & 22.67 & 24.42 & 33.72 & 19.19 \\
Smoked & 41 & 25 & 5 & 46 & 117 & 38.61 & 35.04 & 21.37 & 4.27 & 39.32 \\
Oyster & & & & & & & & & & \\
Fried & 12 & 7 & 5 & 3 & 27 & 8.91 & 44.44 & 25.93 & 18.52 & 11.11 \\
Boiled & 28 & 37 & 50 & 58 & 173 & 57.10 & 16.18 & 21.39 & 28.90 & 33.53 \\
Smoked & 52 & 20 & 10 & 48 & 130 & 42.90 & 40.00 & 15.38 & 7.69 & 36.92 \\
Periwinkle & & & & & & & & & \\
Fried & 8 & 1 & 5 & 0 & 14 & 4.62 & 57.14 & 7.14 & 35.71 & 0.00 \\
Boiled & 48 & 43 & 51 & 69 & 211 & 69.64 & 22.75 & 20.38 & 24.17 & 32.70 \\
Smoked & 30 & 22 & 11 & 31 & 94 & 31.02 & 31.91 & 23.40 & 11.70 & 32.98 \\
Raphia palm & weevil larva & & & & & & & \\
Raw & 2 & 1 & 0 & 0 & 3 & 0.99 & 66.67 & 33.33 & 0.00 & 0.00 \\
Fried & 15 & 6 & 11 & 2 & 34 & 11.22 & 44.12 & 17.65 & 32.35 & 5.88 \\
Boiled & 32 & 20 & 0 & 0 & 52 & 17.16 & 61.54 & 38.46 & 0.00 & 0.00 \\
Smoked & 17 & 18 & 8 & 0 & 43 & 14.19 & 39.53 & 41.86 & 18.60 & 0.00 \\
\hline
\end{tabular}

Source: Field Survey, 2011.

I represent - Ogbolomabiri community, Bayelsa State.

II represent - Bassambiri community, Bayelsa State.

III represent - Okrika community, Rivers State.

IV represent - Isaka community, Rivers State.

TOTAL represent - The total of 301 (respondents out of the total percentage of households sampled).

Table 7. Distribution of respondents based on preferred mode of processing the species

\begin{tabular}{lllllllllll}
\hline \multicolumn{1}{c}{ Frequency } & & & \multicolumn{7}{c}{ Percentage\% } \\
& I & II & III & IV & TOTAL & TOTAL\% & I\% & II\% & II\% & IV\% \\
\hline Preferred mode of processing & & & & & & & & \\
Crab Fried & 0 & 4 & 6 & 0 & 10 & 3.3 & 0 & 40 & 60 & 0 \\
Boiled & 46 & 52 & 45 & 28 & 171 & 56.44 & 26.9 & 30.41 & 26.32 & 16.37 \\
Smoked & 30 & 12 & 2 & 41 & 85 & 28.05 & 35.29 & 14.12 & 2.35 & 48.24 \\
Oyster & & & & & & & & & & \\
Fried & 7 & 5 & 4 & 2 & 18 & 5.94 & 38.89 & 27.78 & 22.22 & 11.11 \\
Boiled & 33 & 44 & 49 & 16 & 142 & 46.86 & 23.24 & 30.99 & 34.51 & 11.27 \\
Smoked & 39 & 15 & 10 & 51 & 115 & 37.95 & 33.91 & 13.04 & 8.7 & 44.35 \\
Periwinkle & & & & & & & & & & \\
Fried & 4 & 0 & 3 & 0 & 7 & 2.31 & 57.14 & 0 & 42.86 & 0 \\
Boiled & 49 & 43 & 47 & 37 & 176 & 58.09 & 27.84 & 24.43 & 26.7 & 21.02 \\
Smoked & 28 & 17 & 8 & 35 & 88 & 29.04 & 31.82 & 19.32 & 9.09 & 39.77 \\
Raphia palm & weevil larva & & & & & & & \\
Raw & 1 & 1 & 0 & 0 & 2 & 0.66 & 50 & 50 & 0 & 0 \\
Fried & 15 & 33 & 10 & 2 & 60 & 19.8 & 25 & 55 & 16.67 & 3.33 \\
Boiled & 32 & 6 & 0 & 0 & 38 & 12.54 & 84.21 & 15.79 & 0 & 0 \\
Smoked & 17 & 11 & 6 & 0 & 34 & 11.22 & 50 & 32.35 & 17.65 & 0 \\
\hline
\end{tabular}

Source: Field Survey, 2011.

I represent - Ogbolomabiri community, Bayelsa State. 
II represent - Bassambiri community, Bayelsa State.

III represent - Okrika community, Rivers State.

IV represent - Isaka community, Rivers State.

TOTAL represent - The total of 301 (respondents out of the total percentage of households sampled).

Table 8. Rationale for preference of the processing methods by the respondents

\begin{tabular}{|c|c|c|c|c|c|c|c|c|c|c|}
\hline & \multicolumn{4}{|c|}{ Frequency } & \multicolumn{6}{|c|}{ Percentage } \\
\hline & I & II & III & IV & TOTAL & TOTAL $\%$ & $\mathrm{I} \%$ & $\mathrm{II} \%$ & $\mathrm{III} \%$ & IV\% \\
\hline \multicolumn{11}{|c|}{ Boiling(Ease of extraction) } \\
\hline & 4 & 1 & 7 & 13 & 25 & 8.25 & 16 & 4 & 28 & 52 \\
\hline & 63 & 63 & 35 & 33 & 194 & 64.03 & 32.47 & 32.47 & 18.04 & 17.01 \\
\hline $\begin{array}{l}\text { Smokin } \\
\text { (taste) }\end{array}$ & 63 & 65 & 14 & 16 & 158 & 52.15 & 39.87 & 41.14 & 8.86 & 10.13 \\
\hline \multicolumn{11}{|c|}{ (longer keep period) } \\
\hline & 10 & 1 & 0 & 1 & 12 & 3.96 & 83.33 & 8.33 & 0 & 8.33 \\
\hline $\begin{array}{r}\text { Frying } \\
\text { (taste) }\end{array}$ & 63 & 10 & 25 & 3 & 101 & 33.33 & 62.38 & 9.9 & 24.75 & 2.97 \\
\hline
\end{tabular}

Source: Field Survey, 2011.

I represent - Ogbolomabiri community, Bayelsa State.

II represent - Bassambiri community, Bayelsa State.

III represent - Okrika community, Rivers State.

IIV represent - Isaka community, Rivers State.

TOTAL represent - The total of 301 (respondents out of the total percentage of households sampled).

\subsection{Nutritional Values of the Species}

Table 9 shows the mineral content of the species from laboratory analysis; Crab was comparatively the richest source of Calcium $(154.00 \mathrm{mg} / 100 \mathrm{~g}$ ) and Magnesium while Periwinkle was the richest in Potassium. Perceived effects of the depletion of these non vertebrate wildlife species on households are presented in Table 10.

Table 9. Nutritional values of the species

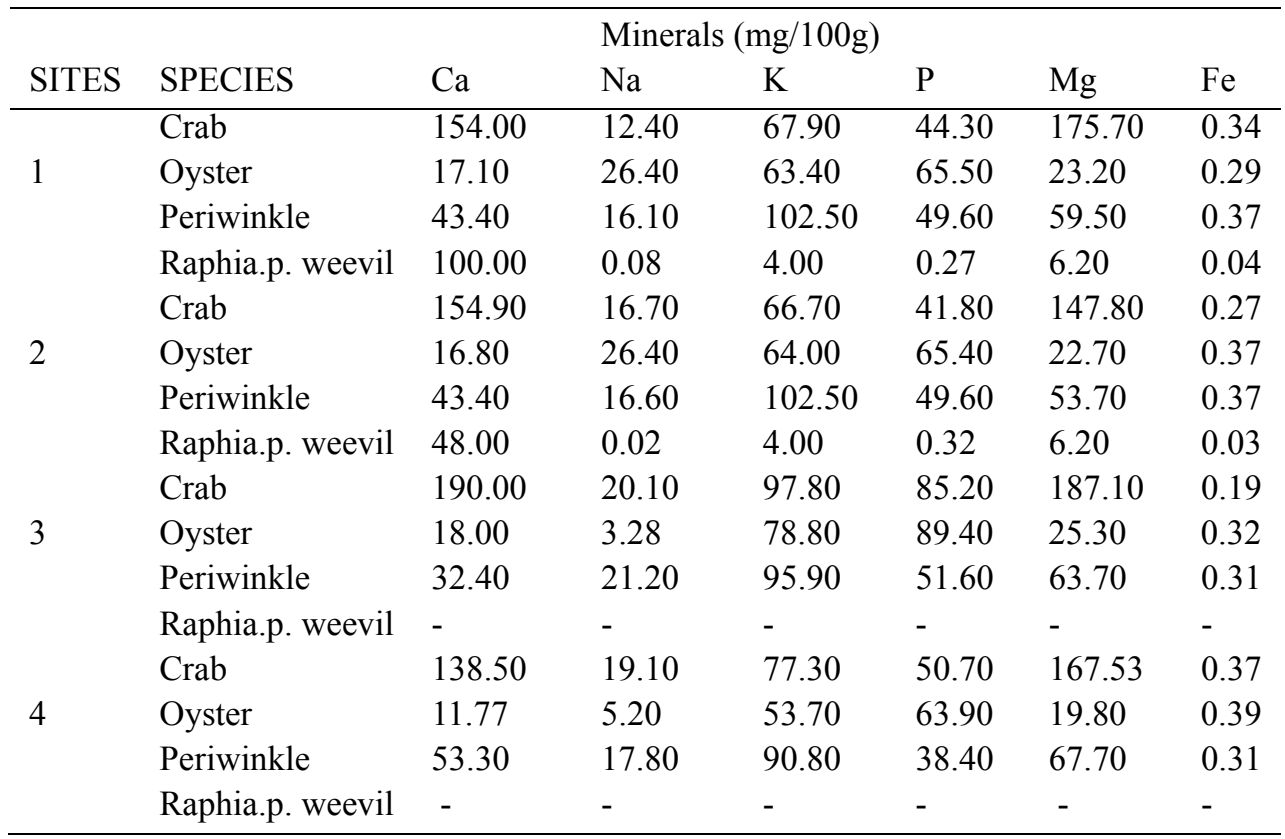


Source: Field Survey, 2011.

1 represent-Ogbolomabiri community, Bayelsa State.

2 represent - Bassambiri community, Bayelsa State.

3 represent - Okrika community, Rivers State.

4 represent - Isaka community, Rivers State.

Table 10. Distribution of respondents based on their perceived effects of species' depletion

\begin{tabular}{llllll}
\hline & TOTAL\% & I $\%$ & II\% & III\% & IV\% \\
\hline Crab & 24.09 & 6.85 & 31.51 & 46.58 & 15.07 \\
Low income & 19.8 & 16.67 & 15 & 41.67 & 26.67 \\
Malnourishment & 1.65 & 0 & 0 & 100 & 0 \\
$\begin{array}{l}\text { Scarcity/Starvation } \\
\text { Oyster }\end{array}$ & & & & & \\
Low income & 24.09 & 9.59 & 24.66 & 35.62 & 30.14 \\
Malnourishment & 27.72 & 29.76 & 25 & 30.95 & 14.29 \\
Scarcity/Starvation & 2.64 & 12.5 & 25 & 62.5 & 0 \\
Periwinkle & & & & & \\
Low income & 16.5 & 0 & 0 & 52 & 48 \\
Malnourishment & 18.48 & 23.21 & 28.57 & 39.29 & 8.93 \\
Scarcity/Starvation & 29.37 & 48.31 & 30.34 & 7.87 & 13.48 \\
Raphia palm weevil larvae & & & & & \\
Low income & 1.98 & 16.67 & 83.33 & 0 & 0 \\
Malnourishment & 2.97 & 44.44 & 33.33 & 22.22 & 0 \\
\hline
\end{tabular}

Source: Field Survey, 2011.

I represent - Ogbolomabiri community, Bayelsa State

II represent - Bassambiri community, Bayelsa State

III represent - Okrika community, Rivers State

IV represents - Isaka community, Rivers State

TOTAL represent - The total of 301 (respondents out of the total percentage of households sampled).

\section{Discussion}

\subsection{Sources and Availability of the Species}

These selected non vertebrate wildlife species are readily available and procured through different means, ranging from harvesting from the wild to purchasing, and the sources of the species are well known to the buyers. Land Crabs can be obtained either as gifts, from neighbours or relatives; by harvesting from the wild (from water or shores/ river banks) or around abodes where they burrow the ground and live in holes. Most respondents buy Crabs and Edible maggots, whereas Oysters and Periwinkles are mainly harvested from the wild by members of households (Table 2). Oyster and Periwinkle are rarely given as gifts in Okrika because they are sold for income generation. Periwinkle is only procured by gifts in Nembe because it is culturally forbidden to sell the species therein.

\subsubsection{Harvesting}

Harvesting of these species is done by most members of households in the rural areas of the communities. This is also obtainable in sub urban and urban areas of the region that are close to river banks as is the case of Abuloma and Fiberesima-ama in Port Harcourt Local Government Area of Rivers State where there are extensions of mangrove swamps. Crab is mostly harvested in the study area by children. This agrees with the findings of Babatunde (2009). Harvesting of Crab is perceived as a cultural role played by this age group (children) in the area. They catch the Callinectes spp. from the mangrove floor (when the river must has ebbed) with the use of local traps made with empty beverage tin and wood, using Pawpaw (Carica papaya) or Onion (Allium cepa) as 
bait. For the water Crab, nets are used to catch them in the river. The period of harvest is at noon of everyday when the water rises and the crabs floating are then caught by the nets set in waters. These species are bought (Table 2) directly from fishermen or traders that buy from them to resell so as to make profit. Similar findings have been reported by Okafor (1994); Ujor (1997) and Udofia, Offiong, Ijeomah and Etefia (2009). Crab is hardly given as gift due to the stress involved in harvesting them (Table 1).

Oysters are harvested by most respondents (64.03\%) of different age groups. Fishermen harvest Oysters by cutting the mangrove roots with the Oysters (reefs), while in canoes or by diving into the water to pick the giant Oysters (Crassostrea gigas), that have probably fallen off the reefs because of their big sizes. The methods of harvesting Oyster are very laborious, and require skills. This can be related to the reason they are rarely obtained through gifts.

In the case of Periwinkle, harvesting is done by most people (almost every one, Table 2) in rural areas of Niger Delta. The species are picked by hand from the floor of the mangrove forests when the river has ebbed. The harvests are put in baskets or bags and stored for later use. These species could be kept for more than three (3) weeks outside water without getting spoilt. The same is applicable to Edible maggot though it can keep for only a maximum period of ten (10) days. Edible maggots inhabit dead or decaying palm species and are harvested by hand picking, after two months or more of adult weevil insect infestations, when the larvae are mature. An indication of the maturity of the larvae is when they make crackling sounds as they feed on the rachis of the palm as is consistent with the report of (Citlali \& Patricia, 2004). The method of harvesting may seem easy but, harvesters suffer mosquitoe and other insect' bites due to the swampy nature of where the species are being harvested from. This therefore discourages people from harvesting it and eventually leads to increases in price of the species, and could be the reason the species is not given as gifts.

a) Challenges involved in harvesting the species

The challenges associated with harvesting of these species are encountered mostly due to lack of modern technology; the fishing tools used by respondents are obsolete and make harvesting inefficient. Harvesting is therefore time-consuming (Table 3). Respondents spend time studying the tide before going to fish, and most times harvesting is done (possible) just once in a day. As water ebbs in the morning respondents move to harvest the species and as it rises later in the day they travel back home in their boats. This is the reason respondents claim that the harvesting of Oyster is difficult and time - consuming (Table 2). Harvesting of Crab is equally time-consuming. More respondents perceive that Oyster is more difficult to harness than Crab. Similarly, harvesting of Paddy (rice) used to be very stressful and time - consuming before a technology that is more efficient and effective was invented by scientists to ameliorate the suffering of rice farmers. Harvesting of Periwinkle is however not difficult, and requires just maneuvering under/around the buttress roots of the mangrove species and picking the species.

b) Trend in the harvesting of species and causes of species decline

Respondents claimed to have noticed decreases in the harvest (catch) of these species (Crab, 49.83\% and Oyster $51.16 \%$ ) in the study area, compared to previous years' harvest (Figure 2). These declines can be attributed to several causes; including over exploitation and pollution.

Water pollution through oil spillage is reducing the population of Oyster in the areas. The oil film surrounds the species, causing difficulties in air exchange and consequently leading to their deaths. Empty opened shells of dead Oysters are sometimes observed on the reefs. Water pollution has as well caused declines in Periwinkle and Crab populations in some areas. Reduced salinity influenced by rainfall also causes declines in Oyster population in the Nembe area. This agrees with FAO (1980). However, this is different from what is obtainable in Okrika, where Oyster is more abundant and less affected due to the large population. In some areas like Isaka, decline is mostly caused by over exploitation due to the fact that most of the inhabitants are fishing and trading on the species. Contrarily, Edible maggots are the most under exploited in the region (Table 2), and water pollution does not directly affect the population of Rhyncophorus phoenicis (unlike the sea foods) because they are not found in the water.

\subsection{Seasonality}

These wildlife species are readily available in most areas of the region. According to most respondents, availability of these species however is affected by seasons, as it determines the species' abundance. Crabs are more abundant during the rainy season unlike the Oyster, Periwinkle and Raphia palm weevil larvae that are more abundant during the dry season (Table 4). Raphia palm maggot is more abundant during the dry season (Figure 3) when the adult weevil insect's flight cannot be hindered by rain that could wet the wings during rainy 
season. Its infestation is severe during dry season as the dry period favours long distance flight as well as reproduction processes in the species.

In the case of Periwinkle, this mollusk aestivates during the rainy season. In spite of the fact that it is found in/around water, it does not thrive well during the rainy seasons. Some remain immobile and others bury into the marshy soil, until conditions become more favourable - in the dry season (Figure 3). This agrees with Tan and Woo (2010). Crabs (land Crab) however are nocturnal and prolific during the rainy season. Interactions with respondents and from indigenous knowledge revealed that more harvests (land Crabs) are observed during the rainy season. This is an indication that this seasonal condition favours the species.

The non vertebrate wildlife species are available most times to the rural people and they are obtained through several means (Figure 3). Since the species are available, majority of the respondents are satisfied with the quantity of the species acquired for use. Non satisfaction of some users can be linked with the time of purchasing. This is because harvesting of Crab (land Crab) is done at night. If it is done in the day little or nothing will be caught as they are nocturnal. This is similar to the time of harvesting the African giant land snail (Archachatina marginata). If $\mathrm{Crab}$ is to be bought, the ideal time of its availability is early in the morning (Table 2). Harvesting and sale of the water Crab is done at noon, when the species is still fresh, though it can still be bought in the evenings. Otherwise, there would be little or none to purchase after this period.

In the cases of Periwinkle and Oyster non satisfaction of users is linked with the high cost of buying them in certain areas, but their availability is not a problem. However, in Nembe boiled Oysters cannot be obtained in the rainy season (Table 5) except those that have been frozen (stored). Dry Oysters are available but also expensive. The Edible maggots' are also highly priced in many cases beyond the reach of few rural poor who buy them. Those who harvest them are sometimes less satisfied especially during the wet periods when they are less productive.

\subsection{Processing Methods}

Different techniques are used by respondents to improve the quality of the species so as to add values to them. The non vertebrate species could be washed, and consumed in raw forms as in the case of the Edible maggot. Few respondents eat it raw (Table 6). Smoking and boiling are also employed in processing non vertebrate wildlife species as is done in the cases of Crab, Oyster and Periwinkle. After heat treatment, the Oyster species are extracted from their shells using knife through a process locally called 'shucking'. The knife is used to crack the shell to remove the Oyster. Contrarily, pin is used to extract the Periwinkle from the shells. Upon extraction, the species are ready to be used in preparing several dishes depending on the preferred methods of processing.

\subsubsection{Preference in Modes of Processing}

Preferred methods of processing the non vertebrate species vary with individuals (Table 7). More than $50 \%$ of the respondents prefer boiling the Crab, Oyster, and Periwinkle, followed by smoking and lastly frying. But for the Edible maggot the preferential ranking was frying, followed by boiling. Only less than one percent preferred it raw. Different ways of processing these species are influenced by certain factors like ease of extraction, as claimed by respondents; most people who trade in the species extract them faster when boiled. This method also adds taste to the species (Table 8) and keeps it fresh, while smoking increases the durability - because the moisture content is reduced discouraging microbial growth. It also adds value to it; however, it is quite stressful. According to respondents frying makes the species tasty as well (Table 8).

\subsection{Contribution of the Species to the Rural Economies}

The utilization of the non vertebrate species as food (Table 2) relative to the abundance has helped largely in sustaining the livelihood of many rural people (Figure 4). According to respondents Crab is sold; tied on sticks, bags (sacks), baskets, basins and trays (Figure 5). The land Crab is majorly sold on sticks: 4 individuals of a species are sold for two hundred (200.00) naira (about 1.29 dollars). However, the price is determined by the quantity required by the users. It could be tied in bags. The water Crab sells for 8 individuals at two hundred (200.00) naira; which is twice as cheap as the former. It is sold mostly in baskets, basins and trays.

Oyster is sold on sticks, in bags, basins and cups; it is mostly sold in cups (Figure 6). Boiled Oyster sells for two hundred (200.00) naira per cup while the dry form sells for as high as four hundred (400.00) naira (about 2.58 dollars) per cup. The amount sold varies with the type of cup used for measurement and the processing methods employed as drying/smoking attracts more cost due to the stress involved.

Interaction with respondents revealed that Periwinkle is mostly sold in cups for between fifty and one hundred and fifty naira per cup, although it (Periwinkle) is also sold in bags at one thousand two hundred naira. Selling of the species in bags is an indication of the species' abundance. It is also sold in plates and trays for fifty naira per 
portion in Okrika, and in baskets. Periwinkle is also sold in custard rubber buckets in Yenagoa, Bayelsa State and other urban, sub-urban areas and markets in Bayelsa and Rivers States.

The Raphia palm weevil larvae are majorly sold on sticks. In the Niger Delta, a notable spot on the major road is the Imbia-ama, Yenagoa junction where these species are sold for two hundred naira per stick with 7-8 Edible maggots. Nevertheless a few respondents claimed that it is sold in rubber buckets and baskets. This shows that it has not been fully exploited (Table 4). The sale of these species in varying quantities is to ensure that they are made available at affordable prices to consumers irrespective of their different income levels.

\subsection{Nutritional Values of the Species}

Foods including the non vertebrate wildlife species are known for nourishing the body, even to the rural people in Niger Delta region. Crabs are given to sick persons in pepper soup, as it is believed that the species helps in blood formation. This can be linked with the nutrient content of the species as confirmed through laboratory analysis (Table 9). Crab contains Iron (between $0.19 \mathrm{mg} / 100 \mathrm{~g}-0.37 \mathrm{mg} / 100 \mathrm{~g}$ in the sites) that helps in formation of heamoglobin. This is in agreement with the report of University of Maryland Medical Centre (2008) that Iron aids in formation of red blood cell and is more absorbed in animal form than in plant form. Though Calcium, Sodium, Potassium, Phosphorus, Magnesium are available in Crab, Oyster, Periwinkle and Edible maggot, the contents vary comparatively (Table 9). Calcium and Phosphorus function in teeth and bone formation and development. Concentration of Phosphorus is highest in Oyster $(63 \mathrm{mg} / 100 \mathrm{~g}-89 \mathrm{mg} / 100 \mathrm{~g})$ while that of Calcium is highest in Crab $(138 \mathrm{mg} / 100 \mathrm{mg}-190 \mathrm{mg} / 100 \mathrm{~g})$ followed by the Raphia palm weevil larvae, Periwinkle and least in Oyster (Table 9).

The edible Oyster flesh is comparatively lowest in Calcium due to the removal of the shell (which contains most Calcium) during processing. The high Calcium in the maggot is because of the plant it feeds on, and as plants are good sources of Calcium. Sodium (averagely) is least available in the edible maggot species but highest in Periwinkle, followed by Crab and Oyster because sea foods coupled with salts in the rivers/banks where they are harvested. Sodium is a major extracellular fluid cation which helps in the maintenance of electrolyte balance, conduction of nerve impulse and muscular contraction. Drying method of processing increases the concentration of sodium. Dried products of these species should therefore be taken in moderation by hypertensive patients as is consistent with BMA (2007). Dry processed meat, sausage and ham contain Sodium, because of the increased concentration of salts due to processing. Sodium is more abundant in Periwinkle than Crab and Oyster and least in the edible maggot; this is the same for Potassium. However, Phosphorus and Iron are relatively most abundant in Oyster followed by Crab, Periwinkle and the Edible maggot while Magnesium is most abundant in Crabs. Regular consumption of $\mathrm{Crab}$ and Oyster by respondents will therefore prevent occurrence of bone malfunction in people in the study area.

\subsection{Possible Effects of Species' Depletion on the People}

The non vertebrate wildlife species are harvested for utilization as food, sources of income, and other vital purposes. Based on these reasons there are use pressures on the species to the extent that the quantities normally harvested by respondents have reduced when compared with the harvest of previous years. This reduction could consequently lead to the depletion of these species, and result in serious impacts like malnourishment and nutrient deficiency diseases on the rural populace (Table 10). More so, food insecurity could increase, the species could become scarce; prices of these species (that are probably gotten from outside sources) will increase, and may increase beyond the reach of the poor rural dwellers. A total depletion of these non vertebrate wildlife species could lead to loss of income generation as the people would no longer trade in the species, consequently an increase in unemployment will result. Respondents who supplement their major income by trading on the species will also be negatively affected. The condition may finally lead to increased crime rate in Niger Delta region and Nigeria at large.

\section{Conclusion}

Crabs, Oyster, Periwinkle and Maggot are abundant in the study area but the quantity harnessed is limited by the traditional and stressful method of harvesting. The species are rich in minerals, and as animals are equally proteinous but further research should be conducted to ascertain the protein content of the species. Researches should also be conducted on improvement of the harvesting strategies of the species. Awareness against unsustainable means of exploitation and environmental pollution should consistently be created in the study areas. 


\section{References}

AOAC. (2000). Association of Official Analytical Chemists. Official methods of analytical Chemists. 18th ed. Washington D.C, pp. 18-62.

Ayodele, I. A., Alarape, A. A., \& Ebin, C. O. (1999). Essentials of Wildlife Management. Jachin Publishers, Ibadan, p. 88 .

Babatunde, E. E. (2009). Assessment of Crab Trap Selectivity and Efficiency in a Tropical Riparian Swamp. African Journal of Biotechnology, 8(18), 4680-4684.

British Medical Association (BMA). (2007). Goitre. Illustrated Medical Dictionary (2nd ed.). Published in the United Kingdom. p. 608.

Citlali, L., \& Patricia, S. (2004). Riches of the Forest for Health Life and Spirit in Africa. Centre for International Forestry Research, Cameroun. p. 11.

Food and Agriculture Organization (FAO). (1980). Culture of the Pacific Oyster (Crassostrea gigas) in the Republic of Korea Corporate Document Repository. Retrieved from http://www.fao.org/docrep/field/003/AB706E/AB706E08.htm

Ijeomah, H. M. (2007). Impact of Tourism on Perceived Poverty Alleviation in Plateau State, Nigeria. PhD Thesis, Department of Wildlife and Fisheries Management, University of Ibadan, p. 301.

Olajide, O. (2003). Steps towards Sustainable Natural Forest for Non Timber Forest Products (NTFPs) in Nigeria. In Oni P. I. (2009). Potentials of a Fallow Plot for Medicinal Plant and Wealth Creation in South Western Nigeria. Global Economic Crisis and Sustainable Renewable Natural Resources Management. Paper presented at the $33^{\text {rd }}$ conference of Forestry Association of Nigeria. In L. Poopola, F. O. Idumah, V. A. J. Adekunle, \& I. O. Azeez (Eds.), Held in Benin-city, Edo State Nigeria between $25^{\text {th }}-29^{\text {th }}$ October, 2010. pp. 514-515.

Omonona, B. T. (2000). Poverty and it's correlates among rural farming households in Kogi, Nigeria. Ph.d. Thesis. Department of Agricultural Economics, University of Ibadan, Nigeria, p. 209.

Panayotou, T., \& Ashton, P. S. (1992). Economics and Ecology for Sustaining Tropical Forests. Island Press Washington D.C. and Covelo, California. In Oni, P. I. (2009). Potentials of a Fallow Plot for Medicinal Plant and Wealth Creation in South Western Nigeria. Global Economic Crisis and Sustainable Renewable Natural Resources Management. Paper presented at the $33^{\text {rd }}$ conference of Forestry Association of Nigeria. In L. Poopola, F. O. Idumah, V. A. J. Adekunle \& I. O. Azeez (Eds.), Held in Benin-city, Edo State Nigeria between $25^{\text {th }}-29^{\text {th }}$ October., 2010, pp. 514-515.

Tan, S. K., \& Woo, P. M. (2010). Preliminary Checklist of the Molluscs of Singapore. Raffles Museum of Biodiversity Research, Singapore. Retrieved from www.rmbr.nus.edu.sg/raffles_museum_pub/preliminarychecklist_mulluscs_singapore.pdf.

Udofia, S. I., Offiong, M. O., Ijeomah, H. M., \& Etefia, J. O. (2009). Non Timber Forest Products in the Household Economy of Ini Local Government of Akwa-Ibom State Nigeria. Nigeria Journal of Agriculture, Food and Environment, 5(1), 52-58.

University of Maryland Medical Centre. (2008). Iron Deficiency Anemia-University of Maryland. Retrieved from http: www.edu/blood/aneiron.htm 